\title{
БАЗОВІ ПОНЯТТЯ ЛІНГВОКУЛЬТУРОЛОГІї: ЛІНГВОКУЛЬТУРА Й ЛІНГВОКУЛЬТУРЕМА
}

Стаття присвячена проблемі виокремлення й інтерпретації базових термінів лінгвокультурології з огляду на ї диференціацію на зіставну та порівняльну. Доведено, шьо необхідно зважати на закріпленість термінів за напрямами лінгвокультурологіi чи іншими науковими напрямами. Термін лінгвокультура є гіперонімом, шьо репрезентує гіпер-гіпонімічні зв'язки 3 гіпонімами національна лінгвокультура чи етнічна лінгвокультура. До базових термінів лінгвокультурології відносимо лінгвокультурему. Пропонуємо розширити перелік їі засобів вираження, включаючи, крім слів, словосполучень, текстів, і звуко-букви, сполучення слів.

Ключові слова: лінгвокультурологія, порівняльна лінгвокультурологія, зіставна лінгвокультурологія, лінгвокультура, національна лінгвокультура, етнічна лінгвокультура, лінгвокультурема, гіпер-гіпонімічні зв'язки.

Koloniuk S. Basic Concept of Linguoculturology: Linguoculture and Linguocultureme. The relevance of the study is determined by the fact that it is completed in accordance with the direction of modern polyparadigmatic linguistics. Attention is focused on the multifunctionality of the terms of linguocultural studies, the necessity of differentiation them according to the specifics of different areas of linguistics. The purpose of this research is to represent the understanding of the basic terms of linguocultural studies, taking into account the research subject, aspects and perspectives of its study, distinguishing them from the basic terms of related sciences. The main terms of linguoculturology include the term linguoculture, which should be considered as a hyperonym, representing hyper-hyponymic connections with the terms national linguoculture or ethnic linguoculture, which compared to the hyperonym, expand their terminological meaning with certain semantic complements and are fixed in the directions of linguoculturology. In a broad sense, linguoculture is a concept that includes the features of the manifestation of national or ethnic linguocultures: these terms should be updated depending on the research intentions, aspects and methods within the contrastive or comparative linguoculturology. The key terms of linguoculturology include the concept of linguocultureme. We propose to expand the list of its means of expression and include word combinations (phraseology), paremias, precedent expressions, as well as asemantic units - sound-letters that contain a powerful pragmatic informative charge in addition to words, phrases and text. A nonverbal sign can also be a means of expression of linguocultureme.

Key words: linguoculturology, contrastive linguocultural studies, comparative linguocultural studies, linguoculture, national linguoculture, ethnic linguoculture, linguocultureme, hyper-hyponymic connections. 


\section{Вступ}

Лінгвокультурологія первинно виникла на межі лінгвістики й культурології та скерована на вивчення зв'язку мовних і культурних явищ (див. про це Алефиренко, 2010: 14; Маслова, 2007: 9; Зиновьева, \& Юрков, 2009: 13). Лінгвокультурологія передусім відповідає на питання про те, «як бачить людина світ, якою $є$ роль метафори й символу в культурі, якою $є$ роль фразеологізмів, що існують у мові віками, у репрезентації культури, чому вони так потрібні людині?» (переклад автор. - С. К.) (Маслова, 2007: 8). Базові поняття лінгвокультурології розглядають провідні науковці сучасності, зокрема М. Алефіренко, С. Воркачов, В. Воробйов, Т. Космеда, Р. Лінтон, Ю. Лотман, В. Маслова, С. Попов, О. Селіванова, Л. Уайт, К. Янг та інші, указуючи на їхні параметричні ознаки та багатоаспектний і міжпредметний статус досліджуваного напряму в сучасному мовознавстві, оскільки «поліфонія гуманітарних наук - це перспектива науки у XXI столітті. Інтеграційні тенденції переважають у вітчизняному й зарубіжному мовознавстві вже від кінця 80-х років ХХ ст. Науковці наголошують, що формується парадигма знання, яка синтезує підходи з різною орієнтацією, що, продовжуючи свій шлях розвитку, формують “поліпарадигмальний” статус сучасної лінгвістики» (Космеда, \& Плотнікова, 2010: 7). Отже, проблема, якій присвячена ця наукова студія, належить до актуальних.

Лінгвокультурологія загальна й лінгвокультурологія компаративна, чи зіставна, зосереджують увагу на зв’язку явищ мови з явищами культури, але не завжди послідовно пояснюють причини існування таких культурних явищ. С. Попов наголошує, що лінгвокультурологія має пояснити причини певних культурних явищ і показати специфіку їх кореляції з мовними явищами (див. Popov, 2018), а для цього, як видається, необхідно уточнити зміст основних понять лінгвокультурології.

А. Загнітко пропонує, як видається, найбільш повну дефініцію терміна лінгвокультурологія, порівн.: «Лінгвокультурологія (лат. lingua - мова + ...культурологія) - розділ мовознавства, що вивчає взаємозв'язок і взаємодію культури і мови в їхньому функціонуванні; узагальнює цей процес як цілісну структуру одиниць в єдності їхнього мовного й культурного змісту за допомогою відповідних методів 3 орієнтацією на сучасні пріоритети та культурні настави (систему 
норм і суспільних цінностей)» (Загнітко, 2012, т. 2: 156). Учений фіксує і факт розгалуження лінгвокультурології на (1) зіставну лінгвокультурологію та (2) порівняльну тінгвокультурологію, зокрема дослідник подає відповідні дефініції: «Лінгвокультурологія (лат. lingua - мова + ...культурологія) зіставна - розділ лінгвокультурології, що досліджує особливості ментальності того чи того народу (національної лінгвокультури) з позицій носіїв його мови і культури в зіставленні 3 носіями інших мов і культур» (Загнітко, 2012, т. 2: 156) та «Лінгвокультурологія (лат. lingua - мова + ...культурологія) порівняльна розділ лінгвокультурології, основною метою і завданнями якого $є$ розгляд лінгвокультурних значущостей і виявів різних народів (національних лінгвокультур) для встановлення певних еволюційних етапів, наявних спільностей та відмінностей» (Загнітко, 2012, т. 2: 157).

Тому, очевидно, для розуміння предмету лінгвокультурології, його базових термінів необхідно чітко визначити дослідницький підхід, що не завжди достатньо точно усвідомлюють науковці.

Констатує А. Загнітко й наявність лінгвокультурознавства як комплексної навчальної дисципліни, порівн.: «Лінгвокультурознавство (лат. lingua - мова + ...культурознавство) - методична дисципліна, метою та завданням якої $€$ відбір і реалізація в навчальному процесі особливостей національно-культурної специфіки мовленнєвого спілкування мовної особистості й національної лінгвокультури для напрацювання відповідних умінь і навичок тими, хто вивчає іноземну мову. Л.[інгвокультурознавство] охоплює два аспекти: 1) лінгвістичний (розгляд мови для вияву національно-культурної семантики); 2) методичний (методи вивчення мови, закріплення й активізації одиниць мови, робота з текстами і под.). Об’єкти Л.[інгвокультурознавства]: безеквівалентна / міжмовна лексика, невербальні засоби спілкування, фразеологія (у широкому тлумаченні), що вивчаються з погляду вияву в національно-ідентифікаційних особливостей певного народу, мова якого вивчається» (Загнітко, 2012, т. 2: 155). Отже, сьогодні теорія лінгвокультурології розширює свій об'єкт і предмет, дефініцію подано з урахуванням аспектуальних підходів.

Мета цієї наукової розвідки - репрезентувати розуміння базових термінів лінгвокультурології з урахуванням дослідницького предмета, аспектів і ракурсів його вивчення, відмежовуючи їх від базових термінів суміжних наук, що здійснюємо із залученням одного 
3 найавторитетніших українських словників лінгвістичних термінів А. Загнітка (2012). До базових термінів лінгвокультурології включаємо такі, як лінгвокультура (національна та етнічна лінгвокультура), лінгвокультурна спільнота, етнічна спільнота, лінгвокультурема.

\section{Методи дослідження}

Для досягнення мети залучаємо низку науково-дослідницьких методів, серед яких основними є описовиц̆, у межах якого актуалізовано прийоми внутрішньої і зовнішньої інтерпретації дослідницького матеріалу, спрямовані на аналіз зазначених базових термінів лінгвокультурології; метод індукиї - для отримання загальних висновків на підставі аналізу вибраних дефініцій, дедукції - у процесі доповнення аналізованих дефініцій; аналізу та синтезу - для здійснення теоретичних узагальнень і систематизації матеріалу, порівняльнозіставний метод - для уточнення специфіки дефініцій, а також метод аналізу словникових дефініцій розглядуваних наукових термінів.

\section{Виклад основного матеріалу}

Термін лінгвокультура, що функціює в метамові лінгвокультурології як порівняно молодого відгалуження етнолінгвістики, належить до базових понять і лінгвокультурології, й етнолінгвістики, і лінгвоконцептології. Крізь призму лінгвокультури можна краще відстежити специфіку комунікації, зокрема й національної, у межах теорії міжкультурної комунікації, оскільки вивчення культури іншої країни дає можливість краще зрозуміти специфіку функціювання кожної конкретної мови, іiі одиниць, бо мова й культура - нероздільні поняття. Лінгвокультура виявляється, як відомо, у національній ментальності та найбільш послідовно віддзеркалюється в (а) лексиці, (б) фразеології, (в) мовленнєвому етикеті, (г) етичних концептах, (г) характері дискурсивної діяльності носія певної культури загалом.

У названому раніше словнику А. Загнітка запропоновано максимально стисле й чітке розуміння терміна лінгвокультура, порівн.: «Лінгвокультура (лат. linqua - мова i cultura - освіта, розвиток) вияв, відбиття і фіксація культури в мові й дискурсі» (Загнітко, 2012, т. 2: 156). Проте, як видається, воно може бути дещо уточнене. Якщо зважати на те, що лінгвокультурологія залучає почергово зіставний (зіставна лінгвокультурологія) чи порівняльний (порівняльна 
лінгвокультурологія) методи дослідження матеріалу як базові, то й тлумачення лінгвокультури як основного поняття зіставного й порівняльного дослідницьких напрямів лінгвокультурології також може уточнюватися.

3 огляду на методологійні положення зіставної лінгвокультурології, лінгвокультуру слід розглядати як вияв, відбиття й фіксацію культури в мові на основі врахування особливостей ментальності того чи того народу з позицій носіїв його мови й культури в зіставленні з носіями інших мов і культур.

Якщо ж дослідження здійснюється в межах порівняльної лінгвокультурології й у наукових студіях актуалізується порівняльний метод, то лінгвокультуру розглядаємо як вияв, відбиття і фіксацію культури в мові на основі аналізу лінгвокультурних значущостей і виявів різних народів для встановлення певних еволюційних етапів, наявних тотожностей та відмінностей.

Це значить, що під час зіставного дослідження проблематики лінгвокультурології йдеться про національну чи національні лінгвокультури, а в процесі порівняльного аналізу актуалізується лінгвокультура етнічна.

3 терміном лінгвокультура тісно пов'язане поняття лінгвокультурна спільнота, що відповідно тлумачиться в словнику А. Загнітка, порівн.: «Спільнота лінгвокультурна (прикм. від ім. лінгвокультура) - єдність етносу, об'єднаних мовою і культурою; спільність етносу, його мови і культури, виявлювана в особливостях спілкування; велика група людей, члени якої можуть належати до того самого або до різних етносів, мати спільну мовну і культурну свідомість; мовна і культурна єдність людей» (Загнітко, 2012, т. 3: 343). Цей термін, як видається, також доцільно використовувати, коли актуалізована проблематика зіставної лінгвокультурології. Натомість за умови досліджень в аспекті порівняльної лінгвокультурології доцільно залучати термін етнічна спільнота, порівн.: «Спільнота етнічна (прикм. від ім. етнос) - мовні особистості, що об’єднані: 1) властивою для них спільною етнічною назвою; 2) спільними міфами тих самих пращурів; 3) спільною історичною пам'яттю; 4) спільними елементами культури (святами, звичаями, традиціями, обрядами, віруваннями); 5) спільною мовою; 6) спільно певною територією; 7) почуттям спільної єдності» (Загнітко, 2012, т. 3: 343). 
У сучасному мовознавстві функціює і термін лінгвокультурна національна спільнота, який А. Загнітко пропонує застосовувати в межах етнолінгвістики, соціолінгвістики та комунікативної лінгвістики, порівн.: «Спільнота національна (прикм. від ім. нація) лінгвокультурна (прикм. від ім. лінгвокультура) - в етнолінгвістиці, соціолінгвістиці, комунікативній лінгвістиці - об’єднання людей (здебільшого таке, що дорівнює нації, етносу) зі спільністю історії, культури (духовної і матеріальної), спільною ідіоетнічною мовою» (Загнітко, 2012, т. 3: 343). Етнолінгвістики, соціолінгвістики та комунікативної лінгвістики, міжкультурної комунікації, зрозуміло, стосується і термін полілінгвокультурна спільнота, порівн.: «Спільнота полілінгвокультурна (грецьк. poly - багато + прикм. від ім. лінгвокультура) - сукупність людей (здебільшого численне) зі спільною історією, проживанням на спільній території тощо з використанням різних культур і використанням різних мов за домінування, зазвичай, однієї» (Загнітко, 2012, т. 3: 343). Функціювання терміна комунікативна спільнота звужує сферу свого активного функціювання до меж комунікативної лінгвістики, порівн.: «Спільнота комунікативна (прикм. від ім. комунікація) (англ. speech community) - спільнота, якій властиві: 1) спільне використання мови; 2) спільні настанови і цінності щодо лінгвістичної форми та її використання; 3) спільні соціокультурні покликання» (Загнітко, 2012, т. 3: 343), проте в зіставній лінгвокультурології доречно вжити термін національна комунікативна спільнота, а в межах порівняльної лінгвокультурології - emнічна комунікативна спільнота.

Поліфункційним терміном, що може обслуговувати всі зазначені вище наукові сфери залежно від дослідницького фокусу, є, як видається, термін інтерпретативні спільноти, порівн.: «Спільноти інтерпретативні (прикм. від ім. інтерпретація) - динамічні групи людей, інколи навіть не знайомих між собою зі спільним культурним досвідом, захопленням, самоідентичністю та дискурсами. Така спільність здебільшого підтримувана і забезпечувана мас-медіа й інформаційними структурами» (Загнітко, 2012, т. 3: 343).

До базового термінополя лінвокультурології належить і термін лінгвокультурема, порівн.: «Лінгвокультурема (лат. lingua - мова + ...культурема) - одиниця аналізу спілкування, комплексне міжрівневе поняття, єдність лінгвального та екстралінгвального культурного 
змісту; поєднує власне-мовні уявлення і відповідні для них позамовні культурні чинники. Засобом вираження є слово, словосполучення, текст. Для Л[інгвокультуреми] характерним є маркування конотативним смислом, який доступний тільки в разі вільного володіння мовою та розумінням культури народу» (Загнітко, 2012, т. 2: 156). Однак, як видається, засобом вираження лінгвокультуреми може бути не лише слово, словосполучення і текст, але й сполучення слів, до яких належать фразеологізми, зокрема й паремійні одиниці в широкому розумінні - прислів'я, приказка, загадка, етикетні формули (вітання, прощання, подяка, побажання та ін.), афоризм, крилатий вислів та ін., тобто широкий масив прецедентних одиниць. Крім того, до лінгвокультуреми можна віднести й звуко-букву, коли вона містить прозору внутрішню форму, що репрезентує прагматичну інформацію, насичену культурним змістом, порівн.: «Букви - це не лише графічні знаки, а дещо більше, оскільки вони вже етимологічно містять певне прагматичне наповнення, що згодом актуалізує можливі рефлексії мовців, формує прагматичні смисли» (Космеда, 2006: 293). На думку Т. Космеди, «лінгвокультура - це феномен, що репрезентує масив інформації, який так чи так пов'язаний з мовою, з кожною іï одиницею. Тому алфавіт, його букви - першоелемент лінгвокульту$\boldsymbol{p u}$ » (Космеда, 2020: 4). Крім того, до засобів вираження лінгвокультуреми слід віднести й засоби невербальної комунікації, що, до речі, здатні й вербалізуватися насамперед у в паремійному фонді, порівн.: «Невербальне пробілювання паремійного матеріалу як інструмент методики вивчення національних параметрів невербальної поведінки крізь призму фразеологіï дає можливість виявити типологійні особливості певної лінгвокультури, специфіку національної комунікативної поведінки, а також з'ясувати пріоритети, що переважають у спілкуванні того чи того етносу, збагатити міжкультурний комунікативний досвід» (Осіпова, 2019: 213).

\section{Висновки}

Отже, до базових термінів лінгвокультурології належить насамперед термін лінгвокультура, який слід розглядати як гіперонім (родове поняття), що репрезентує гіпер-гіпонімічні зв'язки з термінами-конкретизаторами, гіпонімами - національна лінгвокультура чи етнічна лінгвокультура. Ці терміни трактуємо як квазісиноніми, 
оскільки вони допускають лише односторонню заміну. Значення гіпоніма завжди є складнішим, ніж значення гіпероніма. Гіпоніми включають зміст гіпероніма, але розширюють своє термінологічне значення певними семантичними доповненнями, що було продемонстровано.

У широкому розумінні лінгвокультура - це поняття, що включає особливості вияву національних чи етнічних лінгвокультур: ці терміни слід актуалізувати залежно від дослідницьких намірів, аспектів та методики в межах зіставної чи порівняльної лінгвокультурології.

Засоби вираження лінгвокультуреми пропонуємо розширити, залучаючи, крім слова, словосполучення й тексту, ще й сполучення слів (фразеологізми), а також асемантичні одиниці - звуко-букви, що містять потужний прагматичний інформативний заряд. Невербальний знак також може бути виразником лінгвокультуреми.

Перспективу наукової розвідки вбачаємо в необхідності опису ядра метамови лінгвокультурології з урахуванням зіставного й порівняльного їі напрямів.

\section{ЛІТЕРАТУРА}

1. Алефиренко, Н. (2010). Лингвокультурология. Москва: Флинта. 2. Загнітко, А. (2012). Словник сучасної лінгвістики: поняття і терміни. (Т. 2-3). Донецьк: ДоНУ. 3. Зиновьева, Е., \& Юрков, Е. (2009). Лингвокультурология: теория и практика. Санкт-Петербург: Мирс. 4. Космеда, Т. (2020). “Дух” літери, або буква - першоелемент лінгвокультури: відкрита лекція. Кам'янець-Подільський: ОВ «Друкарня “Рута"». 5. Космеда, Т. (2006). Комунікативна компетенція Івана Франка: міжкультурні, інтерперсональні, риторичні виміри. Львів: ПАІС. 6. Космеда, Т. А., \& Плотнікова, Н. В. (2010). Лінгвоконцептологія: мікроконцептосфера СВЯТКИ в українському мовному просторі. Львів: ПАІС. 7. Маслова, В. (2007). Лингвокультурология (3-е изд.). Москва: Академия. 8. Осіпова, Т. (2019). Невербальна комунікація та своєрідність ї омовлення в українському дискурсі: феномен вербалізацї невербаліки. Харків: Вид-во Іванченка I. С. 9. Попов, С. (2018). Лингвокультурология: от констатаций к объяснительности. Traektoriâ Nauki, 4 (4), 1001-1011. DOI: 10.22178/pos.33-1.

\section{REFERENCES}

1. Alefirenko, N. (2010). Lingvokul'turologiya [Linguoculturology]. Moskva: Flinta [in Russian]. 2. Zahnitko, A. (2012). Slovnyk suchasnoi linhvistyky: poniattia i terminy [Dictionary of modern linguistics: concepts and terms]. (T. 2-3). Donetsk: DoNU [in Ukrainian]. 3. Zinov'eva, E., \& Yurkov, E. (2009). Lingvokul'turologiya: teoriya i praktika [Cultural linguistics: theory and practice]. Sankt-Peterburg: Mirs [in Russian]. 4. Kosmeda, T. (2020). "Dukh" litery, abo bukva - pershoelement linhvokultury [The "spirit» of a letter, or letter - the first element of linguistic culture]. Kamianets-Podilskyi: OV «Drukarnia 
"Ruta"» [in Ukrainian]. 5. Kosmeda, T. (2006). Komunikatyvna kompetentsiia Ivana Franka: mizhkulturni, interpersonalni, rytorychni vymiry [Ivan Franko's communicative competence: intercultural, interpersonal, rhetorical dimensions]. Lviv: PAIS [in Ukrainian]. 6. Kosmeda, T. A., \& Plotnikova, N. V. (2010). Linhvokontseptolohiia: mikrokontseptosfera SVIATKY v ukrainskomu movnomu prostori [Linguoconceptology: microconceptosphere HOLIDAYS in the Ukrainian language space]. Lviv: PAIS [in Ukrainian]. 7. Maslova, V. (2007). Lingvokul'turologiya [Linguoculturology] (3rd ed.). Moskva: Akademiya [in Russian]. 8. Osipova, T. (2019). Neverbalna komunikatsiia ta svoieridnist yii omovlennia v ukrainskomu dyskursi: fenomen verbalizatsii neverbaliky [Nonverbal communication and the originality of its verbalization in the Ukrainian discourse: the phenomenon of verbalization of nonverbal]. Kharkiv: Vyd-vo Ivanchenka I. S. [in Ukrainian]. 9. Popov, S. (2018). Lingvokul'turologiya: ot konstatacij k ob»yasnitel'nosti [Linguoculturology: from Ascertaining to Explaining]. Traektoriâ Nauki - The trajectory of Science, 4 (4), 1001-1011. DOI: 10.22178/pos.33-1 [in Russian].

Колонюк Сергій Миколайович - магістр, аспірант кафедри романських мов і світової літератури, Донецький національний університет імені Василя Стуса; пров. Жуковського, 8, м. Вінниця, Україна, 21032.

Tel.: +380679695333

E-mail: kolonyuk777@gmail.com

https://orcid.org/0000-0001-5010-4957

Koloniuk Serhii Mykolaiovych - Master Student, Postgraduate Student at the Department of Romance Languages and World Literature, Vasyl Stus Donetsk National University; 8 Zhukovsky Lane, Vinnytsia, 21032, Ukraine.

Надійшла до редакції 29 грудня 2020 року

\section{CITATION}

ДСТУ 8302:2015: Колонюк С. М. Базові поняття лінгвокультурології: лінгвокультура й лінгвокультурема. Лінгвістичні дослідження: зб. наук. пр. Харк. нац. пед. ун-ту імені Г. С. Сковороди. Харків, 2021. Вип. 54. Ч. І. С. 220-228. DOI: https://doi.org/ $10.34142 / 23127546.2021 .54 .1 .19$

AРА: Колонюк, С. М. (2021). Базові поняття лінгвокультурології: лінгвокультура й лінгвокультурема. Лінгвістичні дослідження, 54 (I), 220-228. DOI: https://doi.org/10. 34142/23127546.2021.54.1.19 